УДК 618.39 - 008.87:616.34

DOI 10.11603/24116-4944.2019.2.10919

(C)О. М. Павловська, К. М. Павловська, Ж. О. Краснова

Одесъкий національний медичний університет

\title{
ОСОБЛИВОСТІ СТАНУ ІНТЕСТИНАЛЬНОЇ МІКРОБІОТИ У ЖІНОК ЗІ ЗВИЧНИМ НЕВИНОШУВАННЯМ ВАГІТНОСТІ
}

Мета дослідження - визначити стан інтестинальної мікробіоти у жінок, які страждають від звичного невиношування вагітності.

Матеріали та методи. Було проведено клініко-лабораторне обстеження 53 жінок у віці 21-46 років, яких поділили на 3 групи. До І групи (n=15) увійшли жінки, у яких відбувся другий або третій поспіль мимовільний викидень у терміні гестації до 22 тижнів, до II групи (n=18) - пацієнтки, у яких відбувся один мимовільний викидень у терміні гестації до 22 тижнів, групу контролю $(\mathrm{n}=20)$ становили пацієнтки у терміні гестації до 22 тижнів, у яких вагітність перебігала без ускладнень. Усім жінкам проводили комплексне об'єктивне й загальноклінічне обстеження згідно з вимогами сучасних клінічних протоколів та загальноприйнятих методик. Стан інтестинальної мікробіоти оцінювали шляхом бактеріологічного дослідження фрекалій одразу ж після мимовільного переривання вагітності. Посіви проводили на відповідні поживні середовища.

Результати дослідження та їх обговорення. У більшості жінок, які страждають від звичного невиношування вагітності, спостерігається виразний дисбаланс інтестинальної мікробіоти, який характеризується значним зменшенням індигенної мікрофлори (Bifidobacterium, Lactobacillus, Escherichia coli, Enterococcus faecium) та посиленим розмноженням таких фракультативних мікроорганізмів, як Staphylococcus epidermidis, Proteus, Klebsiella, Clostridium difficile, Candida albicans.

Висновки. Подальше поглиблене вивчення та аналіз кореляцій між різними таксономічними групами мікробіоти кишечника, яка є своєрідним індикатором стану макроорганізму, є важливим етапом на шляху визначення тригерних механізмів передчасного переривання вагітності. Отже, оцінка кількісного та якісного складу мікробного пейзажу кишечника може стати обов'язковою в алгоритмах обстеження жінок з невиношуванням вагітності. Терапевтична ремодуляція інтестинальної мікробіоти (дієтична, медикаментозна) також може стати одним із важливих фракторів успішності стратегії профрілактики та лікування невиношування вагітності.

Ключові слова: звичне невиношування вагітності; інтестинальна мікробіота; дисбіоз кишечника.

ОСОБЕННОСТИ СОСТОЯНИЯ ИНТЕСТИНАЛЬНОЙ МИКРОБИОТЫ У ЖЕНЩИН С ПРИВЫЧНЫМ НЕВЫНАШИВАНИЕМ БЕРЕМЕННОСТИ

Цель исследования - определить состояние интестинальной микробиоты у женщин, страдающих привычным невынашиванием беременности.

Материалы и методы. Было проведено клинико-лабораторное обследование 53 женщин в возрасте 21-46 лет, которые были разделены на 3 группы. В I группу $(n=15)$ вошли женщины, у которых произошел второй или третий подряд самопроизвольный выкидыш в сроке гестации до 22 недель, во II группу $(\mathrm{n}=18)$ - пациентки, у которых произошел один самопроизвольный выкидыш в сроке гестации до 22 недель, группу контроля $(\mathrm{n}=20)$ составили пациентки в сроке гестации до 22 недель, у которых беременность протекала без каких-либо осложнений. Всем женщинами было проведено комплексное объективное и общеклиническое обследование, согласно требованиям современных клинических протоколов и общепринятых методик. Состояние интестинальной микробиоты оценивали путем бактериологического исследования фрекалий сразу после самопроизвольного прерывания беременности. Посевы осуществлялись на соответствующие питательные среды.

Результаты исследования и их обсуждение. У подавляющего большинства женщин, страдающих привычным невынашиванием беременности, наблюдался выраженный дисбаланс интестинальной микробиоты, который характеризовался значительным уменьшением индигенной микрофрлоры (Bifidobacterium, Lactobacillus, Escherichia coli, Enterococcus faecium) и усиленным размножением таких фракультативных микроорганизмов, как Staphylococcus epidermidis, Proteus, Klebsiella, Clostridium difficile, Candida albicans.

Выводы. Дальнейшее углубленное изучение и анализ корреляций между различными таксономическими группами микробиоты кишечника, которая является своеобразным индикатором состояния макроорганизма, является важным этапом на пути определения триггерных механизмов преждевременного прерывания беременности. Оценка количественного и качественного состава микробного пейзажа кишечника может стать обязательной в алгоритмах обследования женщин с невынашиванием беременности. Терапевтическая ремодуляция интестинальной микробиоты (диетическая, медикаментозная) также может стать одним из важных фракторов успешности стратегии профилактики и лечения невынашивания беременности.

Ключевые слова: привычное невынашивание беременности; интестинальная микробиота; дисбиоз кишечника.

PECULIARITIES OF THE STATE OF THE INTESTINAL MICROBIOTA IN WOMEN WITH HABITUAL MISCARRIAGE

The aim of the study - to determine the state of the intestinal microbiota in women suffering from habitual miscarriage.

Materials and Methods. A total of 53 women aged $21-46$ years were divided into 3 groups. Group I ( $n=15$ ) included women who had the second or third habitual miscarriage in gestation of up to 22 weeks, and group II $(n=18)$ had patients who had one habitual miscarriage in gestation of up to 22 weeks, the control group $(n=20)$ consisted of patients at the gestational age of up to 22 weeks, during which pregnancy progressed without complications. All women were subjected to a comprehensive objective and general clinical examination, in accordance with the requirements of modern clinical protocols and conventional methods. The condition of the intestinal microbiota was assessed by bacteriological examination of faeces immediately after spontaneous abortion. Cultures were performed on the appropriate nutrient media. 
Results and Discussion. The overwhelming majority of the women suffering from habitual miscarriage have a marked imbalance of the intestinal microbiota characterized by a significant decrease in the indigenous microflora (Bifidobacterium, Lactobacillus, Escherichia coli, Enterococcus faecium) and enhanced reproduction of optional microorganisms, such as Staphylococcus epidermidis, Proteus, Klebsiella, Clostridium difficile, Candida albicans.

Conclusions. Further in-depth study and analysis of correlations between different taxonomic groups of the intestinal microbiota, which is a kind of indicator of the state of the macroorganism, is an important step in determining the trigger mechanisms of premature pregnancy termination. Therefore, assessment of the quantitative and qualitative composition of the intestinal microbial landscape may be obligatory in pregnancy screening algorithms for women. Therapeutic remodulation of the intestinal microbiota (dietary, medication) can also be one of the important factors in the success of a strategy to prevent and treat habitual miscarriage.

Key words: recurrent miscarriage; intestinal microbiota; intestinal dysbiosis.

ВСтУП. За даними багатоцентрових міжнародних досліджень, частота невиношування вагітності, незважаючи на досить високий сучасний рівень надання акушерсько-гінекологічної допомоги, не має виразної тенденції до зниження. Як свідчать літературні джерела, цей показник залишається на рівні 12-30 \%, при цьому близько 80 \% репродуктивних втрат відбувається до 22 тижнів гестації $[1,2]$.

Необхідно зазначити, що звичне невиношування вагітності діагностується приблизно у 5 \% жінок, проте ця патологія $€$ мультифакторною, отже, вкрай складною та досі не розв'язаною проблемою сучасного акушерства [3].

Так, дискусійним та спірним на сьогодні залишається питання самого визначення цього поняття. За рекомендаціями ВООЗ (1976р.), звичне невиношування встановлюється при наявності в анамнезі жінки 3 та більше мимовільних абортів поспіль, які відбулись до 20 тижнів гестації [4]. Проте в національних клінічних протоколах багатьох країн світу діагноз звичного невиношування може бути встановлений лікарем за наявності у пацієнтки «двох та більше невдалих клінічних вагітностей поспіль». Крім того, значно відрізняється й граничний термін - у деяких наказах він становить до 20 тижнів гестації, в інших - до 24 тижнів, навіть до 28 [5, 6]. Згідно 3 вітчизняним клінічним протоколом (наказ МОЗ України № 624 від 03.11.2008р.) «звичний аборт», або «звичний викидень», окреслюється як наявність в анамнезі жінки двох або більше вагітностей поспіль, що завершились мимовільним викиднем до 22 тижнів гестації. Також додатково вводяться такі дефініції, як «первинний звичний викидень» та «вторинний звичний викидень» (клінічна ситуація, в якій серії переривань вагітності передувала фрізіологічна, тобто успішна вагітність).

На наш погляд, правомірно стверджувати, що відсутність міжнародного консенсусу щодо загальноприйнятих критеріїв для звичного невиношування вагітності, безумовно, створює певні труднощі при аналізі, інтерпретації та порівнянні результатів клінічних та епідеміологічних досліджень, враховуючи нерівномірний моніторинг когорт, неправильний вибір контролів у такому випадку. Ці методологічні недоліки при статистичній обробці інорормації можуть певною мірою сприяти недооцінці вірогідних ризик-стратисрікаційних маркерів даної патології, що є основою для фрормування стратегій діагностики та есективності лікування.

Не викликає сумнівів те, що звичне невиношування вагітності $є$ однією з надскладних проблем репродуктивної медицини завдяки наявності дуже великого спектра ймовірних тригерних фракторів (генетичні аберації, вплив імунних оракторів, уроджені вади розвитку, гострі та хронічні інфекції, екстрагенітальні захворювання, які потребують лікування, ендокринопатії та ін.) [7-10]. Проте, згідно з сучасними поглядами, саме інфрекційний фрактор найбільш часто $€$ «відповідальним» за фрормування більшості соматичних захворювань. Втім, на сьогодні науковці все більше звертають свою увагу на вплив інтестинальної мікробіоти на формування гомеостазу в організмі. Доведеним є той сракт, що кишкова мікрофрлора шляхом взаємодії з численними ентерорецепторами має значний модулюючий вплив на активність вегетативних, нейроендокринних та імунних реакцій в макроорганізмі, які, в свою чергу, відіграють провідну роль у гестаційних процесах [11].

Тим не менш, у певному відсотку клінічних випадків (до $20 \%$ ) наявна причина звичного невиношування вагітності, незважаючи на всебічне обстеження, залишається невизначеною.

Слід також зауважити, що звичне невиношування вкрай негативно впливає на психоемоційний стан жінки, що, безумовно, знижує її соціально-рольову адаптивність, порушує внутрішньосімейну міжособистісну комунікацію та погіршує психологічний клімат у сім'ї, що загалом може знижувати ефективність лікування та переводити цю проблему вже на рівень психосоматичних захворювань.

Таким чином, дана акушерська проблематика потребує подальшого ґрунтовного та детального дослідження, що дозволить суттєво розширити уявлення науковців і клініцистів про можливі етіопатогенетичні механізми мимовільного переривання вагітності та скласти оптимальні діагностичні алгоритми й персоналізовані схеми лікування.

МЕТА ДОСЛІДЖЕННЯ - визначити стан інтестинальної мікробіоти у жінок, які страждають від звичного невиношування вагітності.

МАТЕРІАЛИ ТА МЕТОДИ. Було проведено клініколабораторне обстеження 53 жінок у віці 21-46 років, яких поділено на 3 групи:

- I група (n=15) - жінки, у яких відбувся другий або третій поспіль мимовільний викидень у терміні гестації до 22 тижнів;

- II група (n=18) - пацієнтки, у яких відбувся один мимовільний викидень у терміні гестації до 22 тижнів;

- III група (n=20) - пацієнтки у терміні гестації до 22 тижнів, у яких вагітність перебігала без ускладнень (група контролю).

Було ретельно вивчено та проаналізовано скарги пацієнток, дані загального та акушерсько-гінекологічного анамнезу. Усім жінкам проводили комплексне об'єктивне й загальноклінічне обстеження згідно з вимогами сучасних клінічних протоколів та загальноприйнятих методик. 
Стан інтестинальної мікробіоти оцінювали шляхом бактеріологічного дослідження фрекалій одразу ж після мимовільного переривання вагітності. Визначали вміст основних представників індигенної мікрофрлори (Bifidobacterium, Lactobacillus, Escherichia coli, Foecal streptococci, Enterococcus faecium) і сракультативних мікроорганізмів (Enterobacter, Citrobacter, Proteus, Klebsiella, Clostridium difficile, Staphylococcus epidermidis, Candida albicans). Посіви проводили на відповідні поживні середовища. Кількісний облік мікроорганізмів, що виросли на жовтково-сольовому агарі, Сабуро, Ендо і 5 \% кров'яному агарі, здійснювали шляхом розрахунку в 1 г випорожнень, враховуючи при цьому дозу засіяного матеріалу і ступінь його розведення.

Для обробки результатів дослідження використовували метод варіаційної статистики і непараметричні методи за допомогою програм «Excel-2000» i «Statistica for Windows v.6.0».
РЕЗУЛЬТАТИ ДОСЛІДЖЕННЯ ТА ЇХ ОБГОВОРЕННЯ.

Першим етапом нашого дослідження було проведення аналізу супутньої соматичної патології в обстежених пацієнток (табл. 1). Виявлено, що найбільш частими хворобами у жінок, які страждають від звичного невиношування вагітності (І група), були ендокринопатії, запальні захворювання органів сечостатевої системи, залізодесріцитна анемія та хронічна артеріальна гіпертензія. У пацієнток з одним мимовільним викиднем в анамнезі найбільш часто діагностували запальні захворювання та залізодефріцитну анемію.

Другим етапом дослідження було проведення аналізу мікробного пейзажу кишечника у жінок трьох груп.

Слід зауважити, що при порівнянні результатів бактеріологічного дослідження фрекалій у пацієнток зі звичним невиношуванням вагітності (I група) був виявлений виразний дисбаланс кишкової мікробіоти, порівняно з пацієнтками II групи і жінками з неускладненою вагітністю (табл. 2). Так, у пацієнток I групи спостерігали

Таблиця 1. Супутні соматичні захворювання у пацієнток зі звичним невиношуванням (I група), мимовільним викиднем в анамнезі (II група) та у вагітних із неускладненим перебігом гестаційного процесу (III група)

\begin{tabular}{|c|c|c|c|c|c|c|}
\hline \multirow{2}{*}{ Соматичні захворювання } & \multicolumn{2}{|c|}{$\begin{array}{c}\text { I група, } \\
\text { n=15 }\end{array}$} & \multicolumn{2}{|c|}{$\begin{array}{l}\text { II група, } \\
\text { n=18 }\end{array}$} & \multicolumn{2}{|c|}{$\begin{array}{c}\text { III група, } \\
\text { n=20 }\end{array}$} \\
\hline & абс. & $\%$ & абс. & $\%$ & абс. & $\%$ \\
\hline Хронічна артеріальна гіпертензія & 5 & 33,3 & 2 & 11,1 & - & - \\
\hline Гіпотиреоз & 2 & 13,3 & - & - & - & - \\
\hline Гіпертиреоз & 1 & 6,7 & - & - & - & - \\
\hline Цукровий діабет & 2 & 13,3 & - & - & - & - \\
\hline Гестаційний цукровий діабет & - & - & 1 & 5,6 & - & - \\
\hline Метаболічний синдром & 4 & 26,7 & - & - & - & - \\
\hline Залізодефіцитна анемія & 7 & 46,7 & 7 & 38,9 & 4 & 20,0 \\
\hline Хронічна венозна недостатність & 3 & 20,0 & 3 & 16,7 & 3 & 15,0 \\
\hline Хронічний бронхіт & 2 & 13,3 & 1 & 5,6 & 1 & 5,0 \\
\hline Хронічний тонзиліт & 3 & 20,0 & 4 & 22,2 & 2 & 10,0 \\
\hline Бронхіальна астма & 1 & 6,7 & - & - & - & - \\
\hline Хронічний пієлонефрит & 6 & 40,0 & 2 & 11,1 & - & - \\
\hline Хронічний цистит & 1 & 6,7 & - & - & - & - \\
\hline Хронічний аднексит & 4 & 26,7 & 5 & 27,8 & 1 & 5,0 \\
\hline Гормональна дисфункція яєчників & 8 & 53,3 & 3 & 16,7 & - & - \\
\hline
\end{tabular}

Таблиця 2. Показники вмісту інтестинальних мікроорганізмів в 1 г фекалій у пацієнток зі звичним невиношуванням (I група), мимовільним викиднем в анамнезі (II група) та у вагітних з неускладненим перебігом

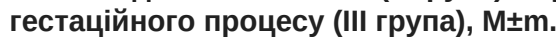

\begin{tabular}{|c|c|c|c|}
\hline Інтестинальні мікроорганізми & $\begin{array}{c}\text { I група, } \\
\text { n=15 }\end{array}$ & $\begin{array}{c}\text { II група, } \\
\text { n=18 }\end{array}$ & $\begin{array}{c}\text { III група, } \\
\text { n=20 }\end{array}$ \\
\hline 1 & 2 & 3 & 4 \\
\hline Lactobacillus, $\left(\times 10^{6}\right)$ & $\begin{array}{c}4,27 \pm 0,18 \\
\left(p_{1-||}<0,001\right) \\
\left(p_{|-| \mid l}<0,001\right)\end{array}$ & $\begin{array}{c}11,48 \pm 0,54 \\
\left(p_{\| I-I I I}=0,410\right)\end{array}$ & $16,76 \pm 6,31$ \\
\hline Bifidobacterium, $\left(\times 10^{8}\right)$ & $\begin{array}{c}2,51 \pm 0,77 \\
\left(p_{1-||}<0,001\right) \\
\left(p_{|-| \mid l}<0,001\right)\end{array}$ & $\begin{array}{c}9,60 \pm 1,76 \\
\left(p_{I I-I I I}=0,003\right)\end{array}$ & $28,34 \pm 5,49$ \\
\hline Foecal streptococci, $\left(\times 10^{6}\right)$ & $\begin{array}{c}0,58 \pm 0,09 \\
\left(p_{1-\mid I}=0,532\right) \\
\left(p_{1-I I I}=0,114\right)\end{array}$ & $\begin{array}{c}0,64 \pm 0,03 \\
\left(p_{11-I I}=0,053\right)\end{array}$ & $0,74 \pm 0,04$ \\
\hline
\end{tabular}


Продовження табл. 2.

\begin{tabular}{|c|c|c|c|}
\hline 1 & 2 & 3 & 4 \\
\hline Escherichia coli, $\left(\times 10^{6}\right)$ & $\begin{array}{l}14,52 \pm 2,17 \\
\left(p_{|-| \mid=0,008)}=0,001\right) \\
\left(p_{|-|||}<0,001\right)\end{array}$ & $\begin{array}{l}33,72 \pm 6,34 \\
\left(p_{I I-I I I}<0,001\right)\end{array}$ & $73,34 \pm 7,58$ \\
\hline Enterococcus faecium, $\left(\times 10^{6}\right)$ & $\begin{array}{l}20,32 \pm 1,08 \\
\left(p_{1-||}=0,001\right) \\
\left(p_{|-| I I}<0,001\right)\end{array}$ & $\begin{array}{l}34,12 \pm 3,75 \\
\left(p_{I I-I I I}=0,098\right)\end{array}$ & $48,76 \pm 7,76$ \\
\hline Staphylococcus epidermidis, $\left(\times 10^{4}\right)$ & $\begin{array}{c}2,14 \pm 0,07 \\
\left(p_{|-|||}<0,001\right) \\
\left(p_{|-|||}<0,001\right)\end{array}$ & $\begin{array}{c}1,02 \pm 0,08 \\
\left(p_{I I-I I I}<0,001\right)\end{array}$ & $0,53 \pm 0,05$ \\
\hline Enterobacter, $\left(\times 10^{3}\right)$ & $\begin{array}{c}3,67 \pm 1,08 \\
\left(p_{1-||}=0,096\right) \\
\left(p_{|-| \mid l}=0,140\right)\end{array}$ & $\begin{array}{c}1,77 \pm 0,23 \\
\left(p_{I I-I I I}=0,307\right)\end{array}$ & $2,03 \pm 0,10$ \\
\hline Citrobacter, $\left(\times 10^{3}\right)$ & $\begin{array}{c}2,99 \pm 0,71 \\
\left(p_{1-||}=0,916\right) \\
\left(p_{1-1 \mid}=0,054\right)\end{array}$ & $\begin{array}{c}2,89 \pm 0,61 \\
\left(p_{I I-I I I}=0,038\right)\end{array}$ & $1,55 \pm 0,12$ \\
\hline Proteus, $\left(\times 10^{3}\right)$ & $\begin{array}{c}4,55 \pm 0,32 \\
\left(p_{1-||}=0,882\right) \\
\left(p_{|-| \mid l}<0,001\right)\end{array}$ & $\begin{array}{c}4,64 \pm 0,51 \\
\left(p_{I I-I I I}=0,003\right)\end{array}$ & $2,43 \pm 0,47$ \\
\hline Klebsiella, $\left(\times 10^{5}\right)$ & $\begin{array}{c}1,18 \pm 0,13 \\
\left(p_{--||}<0,001\right) \\
\left(p_{|-| \mid l}<0,001\right)\end{array}$ & $\begin{array}{c}0,66 \pm 0,04 \\
\left(p_{I I-I I I}<0,001\right)\end{array}$ & $0,22 \pm 0,03$ \\
\hline Clostridium difficile, $\left(\times 10^{5}\right)$ & $\begin{array}{c}1,34 \pm 0,07 \\
\left(p_{1-\mid I}<0,001\right) \\
\left(p_{1-\mid I I}<0,001\right)\end{array}$ & $\begin{array}{c}0,25 \pm 0,03 \\
\left(p_{I I-I I I}=0,105\right)\end{array}$ & $0,19 \pm 0,02$ \\
\hline Candida albicans, $\left(\times 10^{4}\right)$ & $\begin{array}{c}1,26 \pm 0,03 \\
\left(p_{1-||}=0,069\right) \\
\left(p_{|-| I I}<0,001\right)\end{array}$ & $\begin{array}{c}1,37 \pm 0,05 \\
\left(p_{I I-I I I}<0,001\right)\end{array}$ & $0,24 \pm 0,05$ \\
\hline
\end{tabular}

Примітки:

$\mathrm{p}_{\text {--II }}$ - достовірність різниці між показниками I та II груп.

$\mathrm{p}_{\text {I-III }}$ - достовірність різниці між показниками I та III груп.

$\mathrm{p}_{\text {II-III }}-$ достовірність різниці між показниками II та III груп.

значне зменшення основних представників індигенної мікрофрлори та надмірне розмноження фракультативних мікроорганізмів. Так, вміст Lactobacillus, Bifidobacterium та Escherichia coli визначали на рівні $(4,27 \pm 0,18) \cdot 10^{6}$ $\left(p_{|-| \mid}<0,001, p_{|-|||}<0,001\right),(2,51 \pm 0,77) \cdot 10^{8}\left(p_{|-| \mid}<0,001\right.$,

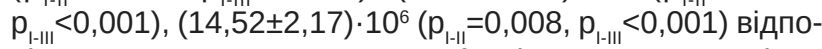
відно. Показники Enterococcus faecium також достовірно були знижені - $(20,32 \pm 1,08) \cdot 10^{6}\left(p_{1-\| 1}=0,001, p_{1-\mid I I}<0,001\right)$, проте вміст Foecal streptococci у фекаліях достовірно не відрізнявся - $(0,58 \pm 0,09) \cdot 10^{6}\left(p_{1-1 \mid}=0,532, p_{1-11}=0,114\right)$.

Вміст Staphylococcus epidermidis, Klebsiella та Clostridium difficile також статистично достовірно відрізнявся від відповідних показників у жінок II групи та контролю: $(2,14 \pm 0,07) \cdot 10^{4}\left(p_{1-||}<0,001, p_{1-|| 1}<0,001\right),(1,18 \pm 0,13) \cdot 10^{5}$ $\left(p_{1-||}<0,001, p_{1-|| l}<0,001\right),(1,34 \pm 0,07) \cdot 10^{5}\left(p_{1-||}<0,001, p_{1-|| \mid}<0,001\right)$. Однак, вміст мікробів роду Proteus та Candida albicans у пацієнток зі звичним невиношуванням та одним мимовільним абортом в анамнезі між собою значно не відрізнялись $-(4,55 \pm 0,32) \cdot 10^{3}\left(p_{\text {I-I }}=0,882\right)$ та $(1,26 \pm 0,03) \cdot 10^{4}$ $\left(p_{1-1 \mid}=0,069\right)$, проте в обох групах були достовірно вищими порівняно з контролем. Лише одна інтестинальна група мікробів Citrobacter у трьох досліджуваних клінічних випадках статистично не відрізнялась між собою.

ВИСНОВкИ. 1. У більшості жінок, які страждають від звичного невиношування вагітності, спостерігається виразний дисбаланс інтестинальної мікробіоти, який характеризується значним зменшенням індигенної мікрофрлори (Bifidobacterium, Lactobacillus, Escherichia coli, Enterococcus faecium) та посиленим розмноженням фракультативних мікроорганізмів (Staphylococcus epidermidis, Proteus, Klebsiella, Clostridium difficile, Candida albicans).

2. Подальше поглиблене вивчення та аналіз кореляцій між різними таксономічними групами мікробіоти кишечника, яка є своєрідним індикатором стану макроорганізму, $€$ важливим етапом на шляху визначення тригерних механізмів передчасного переривання вагітності. Отже, оцінка кількісного та якісного складу мікробного пейзажу кишечника може стати обов'язковою в алгоритмах обстеження жінок із невиношуванням вагітності.

3. Терапевтична ремодуляція інтестинальної мікробіоти (дієтична, медикаментозна) також може стати одним із важливих фракторів успішності стратегії профрілактики та лікування невиношування вагітності.

ПЕРСПЕКТИВИ ПОДАЛЬШИХ ДОСЛІДЖЕНЬ. ДОСЛідити ефективність комплексного медикаментозного лікування жінок, які страждають від звичного невиношування вагітності, на тлі дисбіозу кишечника. Визначити можливі кореляції між виразністю порушень інтестинального мікробіоценозу та мікрофрлорою урогенітального тракту. Детально вивчити особливості призначення дієтотерапії та сучасних про-, пребіотиків у пацієнток із даною акушерською патологією. 


\section{СПИСОК ЛІТЕРАТУРИ}

1. Spontaneous abortion and recurrent miscarriage: $A$ comparison of cytogenetic diagnosis in 250 cases / T. Y. Choi, H. M. Lee, W. K. Park [et al.] // Obstet Gynecol Sci. - 2014. Vol. 57 (6). - P. 518-525.

2. Bacterial vaginosis in association with spontaneous abortion and recurrent pregnancy losses / G. Isik, S. Demirezen, H. G. Donmez, M. S. Beksac // J Cytol. - 2016. - Vol. 33. P. 135-140.

3. Garrido-Gimenez C. Recurrent miscarriage: causes, evaluation and management / C. Garrido-Gimenez, J. AlijotasReig // Postgrad Med J. - 2015. - Vol. 91 (1073). - P. 151-162.

4. WHO: recommended definitions, terminology and format for statistical tables related to the perinatal period and use of a new certificate for cause of perinatal deaths. Modifications recommended by FIGO as amended October 14, 1976 // Acta Obstet Gynecol Scand. - 1977. - Vol. 56 (3). - P. 247-253.

5. Recurrent Miscarriage: Diagnostic and Therapeutic Procedures. Guideline of the DGGG, OEGGG and SGGG / B. Toth, W. Würfel, M. Bohlmann [et al.] // Geburtshilfe Frauenheilkd. - 2018. - Vol. 78 (4). - P. 364-381.

6. Farquharson R. Updated and revised nomenclature for the description of early pregnancy events / R. Farquharson, E. Jauniaux, N. Exalto // Hum. Reprod. - 2005. - Vol. 20. P. 3008-3011.

7. Tur-Torres M. H. Genetics of recurrent miscarriage and fetal loss / M. H. Tur-Torres, C. Garrido-Gimenez, J. AlijotasReig // Best Pract Res Clin Obstet Gynaecol. - 2017. - Vol. 42. - P. 11-25.

8. Recurrent pregnancy loss: current perspectives / H. El Hachem, V. Crepaux, P. May-Panloup [et al.] // Int. J. Womens Health. - 2017. - Vol. 9. - P. 331-345.

9. Планове хірургічне лікування первинного симптомного хронічного захворювання вен у вагітних / В. М. Антонюк-Кисіль, І. Я. Дзюбановський, В. М. Єнікеєва [та ін.] // Актуальні питання педіатрії, акушерства та гінекології. - 2019. - № 1. - С. 43-54.

10. Morphological features of uterine polyps in females of reproductive age / N. Ye. Gorban, T. D. Zadorozhna, I. B. Vovk, I. V. Zhulkevych // Вісник наукових досліджень. - 2019. № 2. - C. 47-52.

11. Sebastián Domingo J. J. From the intestinal flora to the microbiome / J. J. Sebastián Domingo, C. Sánchez Sánchez // Rev Esp Enferm Dig. - 2018. - Vol. - 110 (1). - P. 51-56.

\section{REFERENCES}

1. Choi, T.Y., Lee, H.M., Park, W.K., Jeong, S.Y., \& Moon, H.S. (2014). Spontaneous abortion and recurrent miscarriage: A comparison of cytogenetic diagnosis in 250 cases. Obstet. Gynecol. Sci., 57 (6), 518-525.

2. Isik, G., Demirezen, S., Donmez, H.G., \& Beksac, M.S. (2016). Bacterial vaginosis in association with spontaneous abortion and recurrent pregnancy losses. J Cytol., 33, 135-140.

3. Garrido-Gimenez, C., \& Alijotas-Reig, J. (2015). Recurrent miscarriage: causes, evaluation and management. Postgrad. Med. J., 91 (1073), 151-162.

4. (1977). WHO: recommended definitions, terminology and format for statistical tables related to the perinatal period and use of a new certificate for cause of perinatal deaths. Modifications recommended by FIGO as amended October 14, 1976. Acta Obstet. Gynecol. Scand., 56 (3), 247-253.

5. Toth, B., Würfel, W., Bohlmann, M., Zschocke, J., RudnikSchöneborn, S., \& Nawroth, F. (2018). Recurrent Miscarriage: Diagnostic and Therapeutic Procedures. Guideline of the DGGG, OEGGG and SGGG. Geburtshilfe Frauenheilkd., 78 (4), 364-381.

6. Farquharson, R., Jauniaux, E., \& Exalto, N. (2005). Updated and revised nomenclature for the description of early pregnancy events. Hum. Reprod., 20, 3008-3011.

7. Tur-Torres, M.H., Garrido-Gimenez, C., \& Alijotas-Reig, J. (2017). Genetics of recurrent miscarriage and fetal loss. Best Pract Res Clin Obstet Gynaecol., 42, 11-25.

8. El Hachem, H., Crepaux, V., May-Panloup, P., Descamps P., Legendre, G., \& Bouet, P.E. (2017). Recurrent pregnancy loss: current perspectives. Int. J. Womens Health., 9, 331-345.

9. Antoniuk-Kysil, V.M., Dzubanovskyi, I.Ya., Yenikeeva, V.M., Lincher, S.I., Lypnyi, V.M., \& Zhulkevych, I.V. (2019). Planove khirurhichne likuvannia pervynnoho symptomnoho khronichnoho zakhvoryuvannia ven u vahitnykh [Planned surgical treatment of primary symptomatic chronic vein disease in pregnant women]. Aktualni pytannia pediatrii, akusherstva ta hinekolohii - Actual Problems of Pediatrics, Obstetrics and Gynecology, 1, 43-54 [in Ukrainian].

10. Gorban, N.Ye., Zadorozhna, T.D., Vovk, I.B., \& Zhulkevych, I.V. (2019). Morphological features of uterine polyps in females of reproductive age. Visnyk naukovykh doslidzhen Bulletin of Scientific Research, 2, 47-52 [in Ukrainian].

11. Sebastián Domingo, J.J., \& Sánchez Sánchez, C. (2018). From the intestinal flora to the microbiome. Rev Esp Enferm Dig., 110 (1), 51-56. 